\title{
Perceived Effect of Jibiya Dam on Income Generating Activities of Rural Dwellers of Jibiya Local Government Area of Katsina State, Nigeria
}

\author{
${ }^{1}$ Ikwuakam O.T (Ph.D) (corresponding author) \& Iyela A (PhD) ${ }^{2}$ \\ Federal College of Education, Katsina State, Nigeria \\ Federal College of Education, Okene, Kogi State, Nigeria
}

\begin{abstract}
Water has continually remained germane to the survival of man, plants and animals all over the world. The need to make its availability sustainable all year round using dams is another man's creative ingenuity that may have favourable or unfavourable effects. The study examined the effect of Jibiya dam on income generating activities of rural dwellers of Jibiya Local Government Area of Katsina State. Multi stage sampling procedure was used to generate 120 rural dwellers and information on their socio-economic characteristics, income generating activities and perceived effect was collected using structured interview schedule. Descriptive and inferential statistics were used for data analysis. Most (29.2\%) respondents were between 21-30 years, married (85.0\%), had Quranic education (59.2\%) and mean household size of 7 people. Gathering non-fish aquatic products (95.8\%), processing of fish and other aquatic products (95.0\%), hunting (94.2\%), fishing $(94.2 \%)$ and basket making $(92.5 \%)$ were the income generating activities most respondents were involved. Majority (55.0\%) perceived the effect of the dam on their income generating activities to be favourable. No significant correlation existed between age $(r=0.024 \mathrm{p}=0.72)$, household size $(\mathrm{r}=0.006 \mathrm{p}=$ $0.948)$ and respondents' perceived effect of the dam. Significant difference $(F=6.118, p=0.000)$ was however, recorded between respondents' different educational categories and level of perceived effects of the dam. The efforts of the government in building the dam were not in vain given its favourable effect on people's income generating activities. Awareness creation by relevant stakeholders is germane and need to be intensified if the favourable effect of the dam is to be maximized and sustained.
\end{abstract}

Keywords: Dam, effect, income-generating activities, fishing, non-aquatic products, rural dwellers, basket making

\section{INTRODUCTION}

Given its importance to humans, plants and animal survival, water has continually occupied germane position all over the world. It goes to say therefore that its scarcity to a large extent has become a source of concern to everyone. Thus; the need to make it sustainably available all year round for man, crops and animals has taken the centre stage and tasking to the creative ingenuity of man. Consequently, dam is one of such products of man's creative ingenuity to harness/store water and guide against scarcity.Dams are reservoirs of water held back by barriers (Adewale \& Ikeola 2005) or a structure built across a stream, river or estuary to retain water (Haruna, Kabir \& Aliyu 2010) for man' sustainable us. While some dams are built for a single purpose such as hydro-electric power generation, many are constructed to fulfill diverse functions like water supply for municipal and industrial use; livestock and fish production; flood control; electricity generation, irrigation and tourism (Haruna et al 2010). The importance of dams in the socio-economic life of people and nations has caused a sort of upsurge in its construction over the years. Over 48,000 dams are reported to have been built (ICOLD 1998). Asia $(31,340)$ as a continent ranks first in building dams, followed by North and Central America $(8,010)$ and Europe $(5,480)$. Africa ranks $4^{\text {th }}$ with 1,269 while Australia (577) has the least number of dams (ICOLD 1998). In Africa, South Africa tops the list with 531 dams, followed by Zimbabwe, Morocco and Nigeria that ranks $4^{\text {th }}$ with about 323 dams (Ofoezie 2002). These dams undoubtedly were built to enhance economic growth of the host communities. In other words, the creation of the dams was expected to come with it changes in agriculture, fishing, income generating activities and livelihood diversification, water and electricity supply, roads, housing, health and road infrastructure. In corroboration, Shariff, (2009) \& ICOLD (1998) opined that properly planned, designed, sited, constructed and maintained dams contribute significantly in improving water supply needs, economy, and food production of people. 
Income generating activities are defined to include agricultural production, agricultural wage employment, non-agricultural wage employment, non-farm enterprises, transfers and non-labor income sources (Carletto, Covarrubias, Davis, Krausova, Stamoulis, Winters \& Zezza 2007). It translates to all sorts of coping mechanisms adopted or added by rural dwellers for survival, meet needs and reduce undue pressure on main income generating activity (FAO 2004). It also suggested that engagement in emerging income generating activities is an indication of people making use of new economic opportunities to earn income (Ifejika, Belonwo, Malgwi, Odunuga \& Mbah 2013).Jibiya dam construction was conceived along the socio-economic importance of dams as articulated above. Located in Jibiya LGA of Katsina State, it is an earth-fill structure with a geomembrane liner, measuring $23.5 \mathrm{~m}$ height, 3,660 m length and carrying capacity of $142 \mathrm{million}^{3}$ (Den Hoedt G 1990). The dam was designed in 1987 and completed in 1989 to support irrigation and water supply, enable household income diversification to include and exploit strategic complementary interactions between different activities for income earning and survival against hunger particularly among the rural poor.

However, it is obvious in some cases; dams do have unavoidable adverse effects on people rather than achieving the goals upon which they were established. Thus; while some dams do achieve the goals for their construction others unfortunately are sources of socio-economic hardship on people either in the form of farmlands loss, ecosystems alteration, food losses, disease infections, landlessness or water logging (Roder 1994). It is against this premise the study was conceived to ascertain, however, the effect of Jibiya dam on the income generating activities of rural dwellers in the area.

\section{Statement of problem}

In 1987, the design of Jibiya dam was reportedly conceived while its construction was completed in 1989. It was supposedly aimed at providing support for improved irrigation and water supply; enable household income generation and diversification. This implies that the effects of the dam were to a large extent expected to manifest in the socio-economic and poverty coping mechanisms/activities of the people.

However, it is possible that the dam since inception may have affected people' lives and activities negatively rather than achieving the goals upon which it was established. Roder (1994) had earlier revealed that while some dams do achieve the goals for their construction others unfortunately are sources of socio-economic hardship on people either in the form of farmlands loss, ecosystems alteration, food losses, disease infections, landlessness or water logging. Hunger is also widespread and environmental destruction now a major constraints to economic and social development (Olujide et al 2001). Understandably, these effect (negative or positive) often times is local specific. This infers that the effect of a dam on its immediate environment and people may not be used as a measure for others. It was on this premise that the study was conceived to ascertain what is obtainable in Jibiya.

\section{Objectives}

The general objective of the study is find out the effect of Jibiya dam on the income generating activities of rural dwellers of Jibiya LGA of Katsina State. The specific objectives include to:

1. Examine the socio-economic characteristics of respondents

2. Find out income generating activities of respondents

3. Ascertain perceived effect of Jibiya dam on income generating activities of respondents.

\section{Hypothesis}

There is no significant relationship between respondents' socio-economic characteristics and perceived effect of Ajiwa dam on income generating activities

\section{METHODOLOGY}

The study area is Jibia, a town and one of the 34 Local Government Area (LGA) in Katsina State, Nigeria. The LGA has a population of was approximately 125,000 people and covers an area of about $1037 \mathrm{~km}^{2}$. Jibia sits along on the Nigerian border with Niger and shares common borders with Batsari, Kaita, Katsina, Batagarawa and Zurmi LGAs. The LGA has 12 vilages and plays host to Jibiya Dam. The people are mainly farmers, traders and civil servants. The villages include Bugaje, Dan kar, Dan tambara, Jibiya, Kusa, Mallamawa, and Shimfida. Others are Unguwar Gawa, Unguwar Kaga, Unguwar tagwaje, Unguwar Tsamga and Zandam. The study population comprised of all rural dwellers of Jibiya LGA. Multistage sampling procedure was used in selecting the respondents. In the first stage, $30 \%$ (4) (Bugaje, Jibiya and Dan kar) were purposefully selected out of the 12 villages because of their proximity to the dam. The second stage involved using simple random sampling technique to select thirty rural dwellers from each of the selected LGAs. This gave a sample size of 120 rural dwellers that was used in the study. Structured interview schedule was used to 
collect data on respondents' socio-economic characteristics, income generating activities and perceived effect of the dam on their income generating activities. Involvement in income generating activities was measured using a 2-point scale of involved and not involved with values of 2 and 1 respectively. Respondents' perceived effect was measured on a 5-points scale of Greatly improved, Slightly improved, No effect, Slightly reduced and Greatly reduced with scores of 5, 4, 3, 2 and 1 respectively. The mean perceived effect was obtained and used to categorize level of perceived effect into favourable ( $>$ mean score) and unfavourable ( $<$ mean score). Frequency counts, percentages, mean were used to describe the data while Pearson Product Moment Correlation (PPMC) and Analysis of Variance (ANOVA) were used to test the hypothesis.

\section{RESULTS AND DISCUSSION OF FINDINGS}

\section{Socio-economic characteristics of the respondents}

The socio-economic characteristics of the respondents investigated included age, sex, educational status, household size and religious affiliation. The results as shown on Table 1 revealed that most (29.2\%) respondents were within the age bracket of 21-30 and had a mean age of 38 years. This shows that majority of them were in their young active and productive years, hence they can participate in varied income generating activities. Oyesola (2000) had earlier reported that young adults who fall between the active labour force years are capable of undertaking income generating activities that are labour intensive. Eight five percent of the respondents were married. This means that married people were more involved in income generating activities in the area. The result implies a likelihood that the respondents may rely on family for labour provision. Odebode and Adetunji (2015) had also found that married people were more involved in cassava processing activities in Ogun State, Nigeria. Majority (95.8\%) of the respondents were males. This means that males were adequately involved in income generating activities than the females. The marital status and household size of the respondents may be the reasons for the number of men involved as it is culturally a man's responsibility in most traditional societies in Africa to generate income for households' up keep. The household size of $43.3 \%$ was between 6-10 people and a mean household size of 7 persons. The polygamous life style and extended family relation practiced in the area could be reasons for the high household size. The result suggests that most of the respondents could use members of their households to prosecute their income generating activities. The finding corresponds with that of Adebayo and Muhammad (2011) on the socio-economic determinants of expenditures on food by farm households in Kaduna State, Nigeria. The respondents had one level of education or the other. However, majority (59.2\%) had Quranic education. This explains why most of the respondents were into income generating activities (hired labourer, rope making, gathering of forest products, sale of water and marketing of agro and non agro products) that required little or no formal education to practice. This confirms Ikwuakam and lawal (2015) who stated that most sesame farmers in Batsari Local Government Area possessed Quranic education. Majority (96.7\%) practiced Islamic religion. This means that the respondents were mainly Muslims and explains further why most of them had Quranic education. This is supported by Ikwuakam and Lawal (2015) who noted that most sesame farmers in Batsari LGA of Katsina State were Muslims.

Table 1: distribution of the respondents based on their socio-economic characteristics

\begin{tabular}{|l|l|l|l|}
\hline Variables & F & \% & Mean \pm SD \\
\hline Age: & & & $38.28 \pm 13.15$ \\
$\leq 20$ & 11 & 9.2 & \\
$21-30$ & 35 & 29.2 & \\
$31-40$ & 33 & 27.5 & \\
$41-50$ & 19 & 15.8 & \\
above 50 & 22 & 18.3 & \\
\hline Sex: & & & \\
Male & 115 & 95.8 & \\
Female & 5 & 4.2 & \\
\hline Marital status: & & & \\
Married & 102 & 85.0 & \\
Single & 16 & 13.3 & \\
Divorced & 2 & 1.7 & \\
\hline Educational status: & & & \\
No formal & 6 & 5.0 & \\
Quranic & 71 & 59.2 & \\
Primary & 19 & 15.8 & \\
Secondary & 19 & 15.8 & \\
Tertiary & 5 & 4.2 & \\
\hline
\end{tabular}




\begin{tabular}{|l|l|l|l|}
\hline Household size: & & & $7.02 \pm 4.47$ \\
$1-5$ & 52 & 43.3 & \\
$6-10$ & 44 & 36.7 & \\
$11-15$ & 20 & 16.7 & \\
above 15 & 4 & 3.3 & \\
\hline Religion: & & & \\
Christianity & 3 & 2.5 & \\
Islam & 116 & 96.7 & \\
Traditional & 1 & .8 & \\
\hline
\end{tabular}

Source: Field survey 2016

\section{INCOME GENERATING ACTIVITIES}

Table 2 presents multi responses of the respondents. The results reveal that $6.7 \%$ of the respondents were into fishing as income generating activities which later increased to $94.2 \%$ with the establishment of the dam. Majority $(95.8 \%, 94.2 \%, 53.3 \%$ and $44.2 \%$ of the respondents were involved in gathering non-fish aquatic products, hunting, gathering forest products and civil service. On the other hand, involvement in basket making (92.5\%), processing of fish and other aquatic products (95.0\%), crop farming (88.3\%) and crop processing $(66.7 \%)$ increased tremendously with the coming of the dam. Majority $(53.3 \%, 55.8 \%, 57.5 \%, 51.7 \%, 60.8 \%$, $63.3 \%$ ) also were involved in livestock farming, catering, hired labour, rope making, mechanic, bicycle repairing respectively after the dam was established. Vulcanizing $(60.0 \%)$, marketing $(59.2 \%$, crop processing (59.2\%), marketing of non-agro-products (61.7\%), sale of water (59.2\%) also recorded increased involvement of the respondents. These increases were expected as the dam may have provided enabling environment for robust growth of grasses for livestock production, fishes for catering services and shrubs and forest trees that provided raw materials for basket making, marketing of goods and sources of water to water vendors. These may have brought increases in labour services and hiring, tears and wears of motorcycles and bicycles that were used in transportation services. Such tears and wears were also sufficient to bring about increases in repair services of mechanics and vulcanizes in the area. The results are synonymous with the report of Haruna, Kabir \& Aliyu (2010) that farming, rearing of animals and fishing expanded with construction of Tura dam in Mashigi village of Katsina State, Nigeria.

Table 2: distribution of respondents based on income generating activities

\begin{tabular}{|l|l|l|l|}
\hline Income generating activities & Before & After & Not involved \\
\hline & $\mathrm{F}$ & $\mathrm{F}$ & $\mathrm{F}$ \\
\hline Fishing & $8(6.7)$ & $110(91.7)$ & $2(1.7)$ \\
\hline Gathering non-fish aquatic products & $115(95.8)$ & $5(4.2)$ & $2(1.7)$ \\
\hline Hunting & $113(94.2)$ & $7(5.8)$ & $0(0.00)$ \\
\hline Basket making & $9(7.5)$ & $111(92.5)$ & $0(0.00)$ \\
\hline Processing of fish and other aquatic products & $5(4.2)$ & $114(95.0)$ & $1(0.8)$ \\
\hline Crop farming & $14(11.7)$ & $106(88.3)$ & $0(0.00)$ \\
\hline Crop processing & $35(29.2)$ & $80(66.7)$ & $5(4.2)$ \\
\hline Livestock farming & $46(46.7)$ & $64(53.3)$ & $0(0.00)$ \\
\hline Civil service & $53(44.2)$ & $44(36.7)$ & $23(19.2)$ \\
\hline Gathering forest products & $64(53.3)$ & $56(46.7)$ & $0(0.00)$ \\
\hline Catering & $51(42.5)$ & $67(55.8)$ & $2(1.7)$ \\
\hline Hired laboring & $49(40.8)$ & $69(57.5$ & $2(1.7)$ \\
\hline Rope making & $56(46.7)$ & $62(51.7)$ & $2(1.7)$ \\
\hline Mechanic & $47(39.2)$ & $73(60.8)$ & $0(0.00)$ \\
\hline Bicycle repairing & $44(36.7)$ & $76(63.3)$ & $0(0.00)$ \\
\hline Vulcanizing & $45(37.5)$ & $72(60.0)$ & $3(2.5)$ \\
\hline Marketing of agro-products & $47(39.2)$ & $71(59.2)$ & $2(1.7)$ \\
\hline Crop processing & $47(39.2)$ & $71(59.2)$ & $2(1.7)$ \\
\hline Marketing of non agro-product & $46(38.3)$ & $74(61.7)$ & $0(0.00)$ \\
\hline Sale of water & $48(40.0)$ & $71(59.2)$ & $10(0.8)$ \\
\hline
\end{tabular}

Source: Field survey 2016

\section{PERCEIVED EFFECTS OF AJIWA DAM ON INCOME GENERATING} ACTIVITIES 
Table 3 is a list of items with which respondents' perceived effect of Ajiwa dam were determined. The result shows that involvement in gathering of non-fish aquatic products $(81.7 \%)$, fishing $(80.0 \%)$, processing of fish/other aquatic products (79.2\%), basket making (77.5\%) and hunting (77.5\%) greatly improved as a result of the dam. Greatly improved also are respondents' involvements in crop farming $(74.2 \%)$ and crop processing $(70.0 \%)$. The result further shows that gathering of non-fish aquatic products (mean $=4.63)$, basket making $($ mean $=4.62)$, hunting $($ mean $=4.61)$ and processing of fish/other aquatic products $($ mean $=4.60)$ ranked $1^{\text {st }}$, $2^{\text {nd }}, 3^{\text {rd }}$, and $4^{\text {th }}$ respectively as income generating activities of the respondents. These were followed fishing $(4.59 \%)$, crop farming $(4.485)$, crop processing $(4.46 \%)$ and livestock farming $(4.44 \%)$ that ranked $5^{\text {th }}, 6^{\text {th }}, 7^{\text {th }}$ and $8^{\text {th }}$ respectively. This means that gathering of non-fish aquatic products, basket making, hunting, fishing, crop farming and processing and livestock farming greatly improved due to the dam in the area. The result is contrary to a priori expectation as fishing would have ordinarily ranked first as income generating activity. The result also contradicts the finding of Olujide et al (2001) who found that the effects of dredging the lower Niger River was low on fishing, agriculture and hunting as income generating activities of women in Niger Delta area of Edo State. Table 4 shows that $55.0 \%$ of the respondents perceived the effect of Ajiwa dam on their income generating activities to be favourable while $45.0 \%$ of them perceived it to be low. This implies that there is need for aggressive enlightenment of the people on income generating activities the dam would facilitate.

Table 3: distribution of respondents based on perceived effects of Ajiwa dam

\begin{tabular}{|c|c|c|c|c|c|c|c|}
\hline Perceived effects $(\mathrm{N}=120)$ & $\begin{array}{l}\text { Greatly } \\
\text { improve } \\
\text { d }\end{array}$ & $\begin{array}{l}\text { Slightl } \\
\text { y } \\
\text { improv } \\
\text { ed }\end{array}$ & $\begin{array}{l}\text { No } \\
\text { effect }\end{array}$ & $\begin{array}{l}\text { Sligh } \\
\text { tly } \\
\text { redu } \\
\text { ced }\end{array}$ & $\begin{array}{l}\text { Grea } \\
\text { tly } \\
\text { redu } \\
\text { ced }\end{array}$ & $\begin{array}{l}\text { Me } \\
\text { an }\end{array}$ & $\begin{array}{l}\text { Ra } \\
\text { nk }\end{array}$ \\
\hline Fishing & $96(80.0)$ & $15(12.5$ & 0.00 & $2(1.7$ & $7(5.8$ & 4.59 & $5^{\text {th }}$ \\
\hline $\begin{array}{l}\text { Gathering non-fish aquatic } \\
\text { products }\end{array}$ & $98(81.7)$ & $14(11.7$ & 0.00 & $2(1.7$ & $6(5.0$ & 4.63 & $1^{\mathrm{st}}$ \\
\hline Hunting & $93(77.5)$ & $\begin{array}{l}19(15.8 \\
\end{array}$ & $2(1.7)$ & $\begin{array}{l}0(0.0 \\
0)\end{array}$ & $\begin{array}{l}6(5.0 \\
)^{\prime}\end{array}$ & 4.61 & $3^{\text {ra n }}$ \\
\hline Basket making & 93(77.5) & $20(16.7$ & $1(0.8)$ & $\begin{array}{l}0(0.0 \\
0)\end{array}$ & $\begin{array}{l}6(5.0 \\
)\end{array}$ & 4.62 & $2^{\text {nd } t}$ \\
\hline $\begin{array}{l}\text { Processing of fish/other } \\
\text { aquatic products }\end{array}$ & $95(79.2)$ & $17(14.2$ & 0.00 & $1(0.8$ & $\begin{array}{l}7(5.8 \\
)\end{array}$ & 4.60 & $4^{\operatorname{th} h}$ \\
\hline Crop farming & $89(74.2)$ & $20(16.7$ & 0.00 & $2(1.7$ & $\begin{array}{l}9(7.5 \\
)\end{array}$ & 4.48 & $6^{\text {th }}$ \\
\hline Crop p & $84(70.0)$ & $25(20.8$ & $1(0.8)$ & $2(1.7$ & $8(6.7$ & 4.46 & $7^{\text {th }}$ \\
\hline Livestock $\mathrm{f}$ & $78(65.0)$ & $32(26.7$ & $1(0.8)$ & $3(2.5$ & $6(5.0$ & 4.44 & $8^{\text {th }}$ \\
\hline$\overline{\text { Civil s }}$ & $20(16.7)$ & $3(2.5)$ & $\begin{array}{l}59(46 . \\
2)\end{array}$ & $\begin{array}{l}28(2 \\
3.3)\end{array}$ & $\begin{array}{l}10(8 . \\
3)\end{array}$ & 2.96 & $9^{\text {th }}$ \\
\hline Gathering fore & $10(8.3)$ & $25(20.8$ & $\begin{array}{l}19(15 . \\
8)\end{array}$ & $\begin{array}{l}55(4 \\
5.8)\end{array}$ & $\begin{array}{l}11(9 . \\
2\end{array}$ & 2.73 & $12^{\text {th }}$ \\
\hline Catering & $7(5.8)$ & $\begin{array}{l}31(25.8 \\
\end{array}$ & $9(7.5)$ & $\begin{array}{l}.06(5 \\
5.0) \\
\end{array}$ & $7(5.8$ & 2.71 & $13^{\text {th }}$ \\
\hline Hired laboring & $12(10.0)$ & $33(27.5$ & $6(5.0)$ & $\begin{array}{l}61(5 \\
0.8) \\
\end{array}$ & $\begin{array}{l}8(6.7 \\
)\end{array}$ & 2.83 & $10^{\text {th }}$ \\
\hline Rope & $8(6.7)$ & $29(24.2$ & $\begin{array}{l}15(12 . \\
5)\end{array}$ & $\begin{array}{l}56(4) \\
6.7)\end{array}$ & $\begin{array}{l}12(1 \\
0.0)\end{array}$ & 2.71 & $13^{\text {th }}$ \\
\hline Mechanic & $6(5.0)$ & $27(22.5$ & $8(6.7)$ & $\begin{array}{l}64(5 \\
3.3)\end{array}$ & $\begin{array}{l}15(1 \\
2.5)\end{array}$ & 2.54 & $14^{\text {th }}$ \\
\hline Bicycle repairing & $5(4.2)$ & $\begin{array}{l}23(19.2 \\
)\end{array}$ & $\begin{array}{l}12(10 . \\
0)\end{array}$ & $\begin{array}{l}58(4 \\
8.3)\end{array}$ & $\begin{array}{l}22(1 \\
8.3)\end{array}$ & 2.43 & $16^{\text {th }}$ \\
\hline Vulcanizing & $6(5.0)$ & $\begin{array}{l}22(18.3 \\
\end{array}$ & $\begin{array}{l}12(10 . \\
0)\end{array}$ & $\begin{array}{l}59(4 \\
9.2)\end{array}$ & $\begin{array}{l}21(1 \\
7.5)\end{array}$ & 2.44 & $15^{\mathrm{th}}$ \\
\hline
\end{tabular}




\begin{tabular}{|c|c|c|c|c|c|c|c|}
\hline Marketing of agro-products & 19(15.8) & $\begin{array}{l}25(20.8 \\
)\end{array}$ & $6(5.0)$ & $\begin{array}{l}46(3 \\
8.3)\end{array}$ & $\begin{array}{l}24(2 \\
0.0)\end{array}$ & 2.74 & $11^{\text {th }}$ \\
\hline Transportation & $6(5.0)$ & $22(18.3$ & $5(4.2)$ & $\begin{array}{l}62(5 \\
1.7)\end{array}$ & $\begin{array}{l}25(2 \\
0.8)\end{array}$ & 2.35 & $17^{\text {th }}$ \\
\hline $\begin{array}{l}\text { Marketing of non agro- } \\
\text { product }\end{array}$ & $9(7.5)$ & $\begin{array}{l}17(14.2 \\
)^{1}\end{array}$ & $4(3.3)$ & $\begin{array}{l}61(5 \\
0.8) \\
\end{array}$ & $\begin{array}{l}29(2 \\
4.2) \\
\end{array}$ & 2.30 & $19^{\text {th }}$ \\
\hline Sale of water & $6(5.0)$ & $\begin{array}{l}23(19.2 \\
)\end{array}$ & $4(3.3)$ & $\begin{array}{l}60(5 \\
0.0) \\
\end{array}$ & $\begin{array}{l}27(2 \\
2.5) \\
\end{array}$ & 2.34 & $18^{\text {th }}$ \\
\hline $\begin{array}{l}\text { Vocational } \\
\text { skills/development }\end{array}$ & $5(4.2)$ & $\begin{array}{l}23(19.2 \\
{ }^{2}\end{array}$ & $4(3.3)$ & $\begin{array}{l}55(4 \\
5.8) \\
\end{array}$ & $\begin{array}{l}33(2 \\
7.5) \\
\end{array}$ & 2.27 & $20^{\text {th }}$ \\
\hline Employment & $4(3.3)$ & $\begin{array}{l}18(15.0 \\
{ }^{2}\end{array}$ & $7(5.8)$ & $\begin{array}{l}63(5 \\
2.5) \\
\end{array}$ & $\begin{array}{l}28(2 \\
3.3) \\
\end{array}$ & 2.22 & $21^{\mathrm{st}}$ \\
\hline
\end{tabular}

Source: Field survey $2016 *$ Percentages in parentheses

Table 4: distribution of respondents based on level of perceived effects of Ajiwa dam

\begin{tabular}{|l|l|l|l|l|l|l|l|l|}
\hline Levels & $\mathrm{F}$ & $\%$ & $\begin{array}{l}\text { Range of } \\
\text { score }\end{array}$ & $\begin{array}{l}\text { Minimum } \\
\text { Score }\end{array}$ & $\begin{array}{l}\text { Maximum } \\
\text { Score }\end{array}$ & Mean & SD \\
\hline $\begin{array}{l}\text { Unfavoura } \\
\text { ble }\end{array}$ & $\begin{array}{l}54 \\
66\end{array}$ & $\begin{array}{l}45.00- \\
0\end{array}$ & $\begin{array}{l}34.00 \\
73.00 \\
\begin{array}{l}\text { Favourabl } \\
\text { e }\end{array}\end{array}$ & $\begin{array}{l}54.00- \\
0\end{array}$ & $\begin{array}{l}34.00 \\
99.00\end{array}$ & 99.00 & 74.14 & 13.87 \\
\end{tabular}

Source: Field survey 2016

\section{HYPOTHESIS TESTING}

The result of the analysis as shown in Table 5 indicates that significant relationships did not exist between age $(r=0.024)$, household size $(r=0.006)$ and respondents' perceived effect of Ajiwa dam on their income generation activities. This implies that income generating activities involved by respondents were not functions of their age and household size. The result is not in tandem with the finding of Okoro (2004) that age and household size were functions of assuming more responsibilities. The result of one way ANOVA analysis on Table 6 shows that there is a significant difference $(F=6.118, p=0.000)$ in respondents' perceived effect of Ajiwa dam on income generating activities across different educational categories. This means that respondents' perceptions differ from one another. The result is line with a priori expectation due to the role different educational levels can play in the way people perceive and do things. A post hoc test of multiple comparisons as shown in Table 7 further reveals that primary school holders $(83.84 \pm 10.30)$ had the highest level of perceived

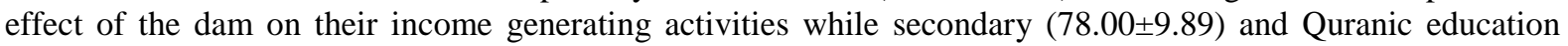
(72.37 \pm 12.98$)$ were not significantly different from each other. However, primary and secondary school holders

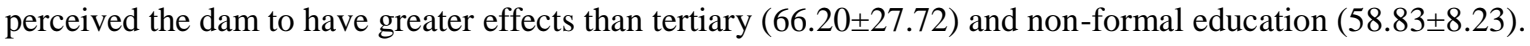

Table 5: Pearson product Moment Correlation (PPMC) analysis of the relationship between respondents' age, household size and perceived effects

\begin{tabular}{|l|l|l|l|}
\hline Independent variables & r & P & Decision \\
\hline Age & 0.024 & 0.792 & Not Significant \\
Household size & 0.006 & 0.948 & Not Significant \\
\hline
\end{tabular}

Table 6: showing analysis of variance of difference among educational categories and perceived effect of Ajiwa dam on income generating activities

\begin{tabular}{|l|c|l|l|l|l|l|}
\hline & $\begin{array}{c}\text { Sum of } \\
\text { Squares }\end{array}$ & \multicolumn{1}{|c|}{ Df } & Mean Square & F & $\begin{array}{l}\text { P- } \\
\text { value }\end{array}$ & Decision \\
\hline $\begin{array}{l}\text { Between } \\
\text { Groups }\end{array}$ & 4015.953 & 4 & 1003.988 & 6.118 & 0.000 & $\begin{array}{l}\text { Significa } \\
\text { nt }\end{array}$ \\
\hline $\begin{array}{l}\text { Within } \\
\text { Groups }\end{array}$ & 18870.639 & 115 & 164.093 & & & \\
\hline Total & 22886.592 & 119 & & & & \\
\hline
\end{tabular}


Table 7: Duncan analysis of separation of means of different educational categories for different educational categories

\begin{tabular}{|c|c|c|c|c|}
\hline Educational Status & $\mathbf{N}$ & \multicolumn{3}{|c|}{ Subset for alpha $=.05$} \\
\hline & & 1 & 2 & 3 \\
\hline No formal & 6 & $58.8333 \pm 8.232$ & & \\
\hline Tertiary & 5 & $66.2000 \pm 27.716$ & $66.2000 \pm 27.716$ & \\
\hline Quranic & 71 & & $72.3662 \pm 12.978$ & $\begin{array}{l}72.3662 \pm 12.97 \\
8\end{array}$ \\
\hline Secondary & 19 & & & $78.0000 \pm 9.888$ \\
\hline Primary & 19 & & & $\begin{array}{l}83.8421 \pm 10.29 \\
7\end{array}$ \\
\hline Sig. & & 0.195 & 0.277 & 0.056 \\
\hline
\end{tabular}

\section{CONCLUSION AND RECOMMENDATIONS}

From the findings of the study, it can be concluded that gathering non-fish aquatic products, processing of fish and other aquatic products, hunting, fishing and basket making were the income generating activities most respondents were involved after the establishment of the dam. It can also be concluded that the effect of Ajiwa dam on income generating activities of the people was perceived to be favourable. Based on this conclusion, the following recommendations are made:

1. There is need for a robust awareness creation by relevant stakeholders on the dams' objectives to enable rural dwellers maximize its use

2. Government and non-governmental agencies should organize training programmes on those income generating activities most rural dwellers seemed not to have explored since the establishment of the dam

3. Further studies should be carried out on various income generating activities that could be tried out within and around the dam area and rural dwellers' skill needs

\section{REFERENCES}

[1] Adebayo, C.O \& Muhammad, H.U (2011). Socio-economic determinants o Expenditure on food by farm households in Kaduna State, Nigeria. NJRS Vol. 12, No 2

[2] Adewale J. G. \& Ikeola R.F (2005). Resettlement Coping Strategies of Women Settlers Around Dams in Nigeria: A Case Study of Erelu Dam in Oyo, Oyo State, Nigeria. J. Hum. Ecol., 17(3): 177-181

[3] Carletto G., Covarrubias K Davis B., Krausova M., Stamoulis K., Winters P \& Zezza A (2007). Rural income generating activities in developing countries: Re-assessing the evidence. Electron. J. Agric. Dev. Econ., 4: 146-193.

[4] Den Hoedt G (1990). Geotextiles, Geomembranes and Related Products: Canals, reservoirs and dams. Taylor \& Francis. P49

[5] FAO, (2004). Guidelines on the collection of demographic and socio-economic information on fishing. Communities for use in Coastal and Aquatic Resources Management. FAO Fisheries Technical Paper, 439. 23

[6] Haruna S, Kabir I \& Aliyu I.K (2010). Economic impact of dam construction, the challenge and solution to agricultural productivity in Nigeria: a case study of Tura dam in mashigi village, kankara L.G.G Katsina State. Journal of Agriculture and Veterinary Sciences. Volume 2, 35-44 www.cenresin.org/retrived 12/09/2016

[7] Ifejika, P.I Belonwu, E.N, Malgwi, Y.Y, Odunuga, A.O and Mbah A.A (2013). Emerging Income Generating Activities of Fisherfolk in Riverine Communities of Niger State, Nigeria. Journal of Fisheries and Aquatic Science, 8: 706-713.

[8] Ikwuakam and Lawal M (2015). Sesame Farmers' Access to Intervention Input in Batsari Local Government Area of Katsina State, Nigeria. Nigerian Journal of Rural Extension and Development - Vol. $9,7-12$

[9] International Commission on large Dams ICOLD (1998). ICOLD- http://www.icoldcigb.net/GB/Dams/dams environment.asp

[10] Odebode, S.O \& Adetuji T.A (2015). Gender Differentials of Cassava Processing Activities among Cassava Processors in Ogun State, Nigeria. Nigerian Journal of Rural Extension and Development - Vol. $9,1-6$

[11] Ofoezie I. E. (2002). Human Health and Water Resources Development in Nigeria: Schistosomiasis in Artificial Lakes. Natural Resources Forum. 26: 150-159 
[12] Okoro G (2006). Percieved effects of oil spillage on the livelihood activities of women in Eastern Obolo LGA of Akwa-Ibom State. An M.SC thesis in the Department of Agricultural Extension and Rural Development. University of Ibadan

[13] Olujide M.G, Oladele I.O \& Hassan O.C (2001). Perceived effects of Dredging of the lower niger River on income generating activities of women in Niger delta Area of Edo State. in (eds) The Nigeria Economic Society (NES). Natural resources use, the environment and sustainable development. 283-294

[14] Oyesola, O.B (2000). Training needs for improving income generating activities ofagro pastoral women in Ogun State, Nigeria. Unpublished Ph.D thesis, Department od Agricultural Extension and Rural Development, University of Ibadan, Nigeria, 236

[15] Roder, W. (1994). Human Adjustments to Kainji Reservoir in Nigeria. University Press of America, New York, London.

[16] Shariff, U (2009). Politics of River Basin Authorities. Daily Trust, Tuesday April 14, 11. 